\title{
PENINGKATAN PENDIDIKAN DAN PENGEMBANGAN KOMPETENSI GURU SMA NEGERI 1 KATAPANG MELALUI PARTISIPASI DALAM PUBLIKASI AKADEMIS DI MEDIA MASSA
}

\author{
Hafiar, H., Damayanti, T., Subekti, P. dan Fatma, D. \\ Fakultas Ilmu Komunikasi Universitas Padjadjaran \\ E-mail: hannyhafiar@yahoo.com
}

\begin{abstract}
ABSTRAK
Budaya menulis semakin tumbuh dan berkembang di kalangan guru. Adanya perkembangan teknologi disatu pihak informasi memfasilitasi dan memudahkan guru untuk mencari inspirasi, mengumpulkan bahan tulisan, menulis berbagai jenis tulisan, dan mempublikasikannya melalui media. Alat perekam memudahkan guru merekam aktivitas mengajarnya dan kemudian memindahkannya ke dalam video atau ke dalam teks. Membaca dan menulis adalah sebuah kewajiban bagi guru untuk mengembangkan wawasan dan mengembangkan potensi diri agar mampu mengajar anak didik dengan lebih baik. Terlebih kini guru juga dituntut untuk membuat penelitian tindakan kelas dan mempublikasikan hasil penelitiannya. Namun, tidak semua guru memiliki kompetensi untuk menuangkan gagasannya ke dalam bentuk tulisan. Hal itu disebabkan oleh metode ajar yang dilakukan para guru yang cenderung bersifat komunikasi lisan dan tatap muka di kelas. Untuk itu pelatihan menulis artikel sebagai bahan publikasi ilmiah bagi guru sangatlah diperlukan untuk meningkatkan kompetensi mereka sebagai pendidik. Metode pelaksanaan pelatihan ini dimulai dengan tahap persiapan, pelak-sanaan dan evaluasi. Pelasanaan menggunakan metode ceramah dan praktik langsung menulis artikel ilmiah dan dikirimkan ke berbagai media massa yang menyediakan kolom khusus bagi guru.
\end{abstract}

Kata kunci: pelatihan, menulis, publikasi, media massa, guru.

\section{PENDAHULUAN}

Lahirnya Permeneg Pendayagunaan Aparatur Negara dan Reformasi Birokrasi No.16 Tahun 2009 berimplikasi terhadap jabatan guru dan pengusulan kenaikan pangkat melalui penetapan angka kredit. Peraturan baru itu terdiri atas $13 \mathrm{Bab}$ dan 47 pasal; secara keseluruhan mengandung semangat yang bertujuan untuk meningkatkan kompetensi dan profesionalisme guru sebagai tenaga profesional yang mempunyai fungsi untuk meningkatkan mutu pendidikan nasional sebagaimana diamanatkan dalam Undang-undang No. 14 Tahun 2005 Pasal 4.

Semangat untuk meningkatkan profesionalisme guru tersebut antara lain terlihat dengan adanya kewajiban bagi guru golongan III-b untuk membuat publikasi ilmiah atau karya inovatif. Seandainya setiap guru dibiasakan untuk mendokumentasikan dengan baik apa yang telah dilakukan dalam pembelajaran, bukan hal yang musykil untuk memenuhi kewajiban itu. Hal itu masih menjadi beban bagi guru karena kegiatan itu belum terbiasakan. Dalam pengusulan kenaikan pangkat dan jabatan guru dari golongan IV-a ke IV-b, para guru wajib untuk menyerahkan minimal satu karya tulis hasil penelitian dan satu artikel yang terbit di jurnal. Tuntutan kewajiban itu merupakan tantangan yang harus disikapi dan dihadapi.
Dilihat dari perspektif guru sebagai subjek, sebagai praktisi pendidikan, para guru memiliki potensi menulis yang sangat besar. Guru sebenarnya memiliki segudang bahan berupa pengalaman pribadi tentang sistem dan model pembelajaran yang dijalankan. Guru dapat menulis tentang indahnya menjadi guru atau dapat juga menuliskan pengalaman suka-duka menjadi guru. Guru dapat juga memaparkan sisi-sisi kehidupan guru dan sebagainya. Di pihak lain, sebagai objek, selama ini banyak orang menjadikan guru sebagai bahan perbincangan dan sebagai bahan tulisan. Berupa aturan dan hukum mengenai profesi guru yang semakin marginal ini. Berbagai keprihatinan terhadap profesi guru yang semakin langka itu dapat menjadi sejuta bahan untuk ditulis. Sayangnya, tulisan-tulisan mengenai guru kebanyakan tidak ditulis oleh para guru. Padahal, jika semua itu ditulis oleh guru, penulisan oleh sang guru itu akan menjadi sebuah proses pembelajaran bagi semua orang.

Rooijakkers (1991:189-228) dalam bukunya yang bertajuk Mengajar dengan Sukses memberi petunjuk kepada seorang guru yang ingin mengajar dengan sukses, yang salah satu adalah keterampilan guru dalam membuat karya ilmiah atau tulisan lain yang bertujuan untuk mempermudah terjadinya proses belajar di pihak siswa. Guru tidak cukup hanya berbicara di muka kelas saja tetapi usaha itu perlu dibarengi dengan berkomunikasi lewat media seperti misalnya modul, diktat, makalah atau tulisan ilmiah.

Berkaitan dengan perlunya seorang guru menulis bahan mengajar juga direkomendasikan oleh Tjipto Utomo dan Kees Ruijter (1991) melalui bukunya yang berjudul Peningkatan dan Pengembangan Pendidikan. Mereka antara lain menulis bahwa dalam mengajar, seorang guru perlu mempersiapkan segala sesuatunya berkaitan dengan proses belajar siswa, termasuk antara lain adalah membuat modul untuk bahan kelengkapan belajar mandiri di kalangan siswa.

Di jaman sekarang, seorang guru tidak mungkin lagi dapat menguasai seluruh perkembangan informasi pendidikan yang semakin mengompleks. Bahkan tidak jarang seorang guru harus berusaha keras karena merasa tertinggal menghadapi para siswa yang banyak membaca. Bukankah perkembangan informasi dewasa ini sangat sulit bisa diikuti oleh seorang ahli sekalipun, mengingat perkembangannya yang semakin kompleks (Yusup 1995).

Hasil penelitian dapat dalam bentuk penelitian tindakankelasatau dalambentukbukusebagaiupayauntuk meningkatkan profesionalisme guru karena penelitian yang dilakukan tak jauh dari apa yang dilakukannya dalam proses belajar mengajar. Penelitian tindakan kelas yang dilakukan oleh guru dapat meningkatkan kualitas belajar mengajar dan mutu layanan pendidikan yang diberikan kepada peserta didik.

Hal yang perlu mendapatkan perhatian adalah artikel yang diterbitkan di jurnal ilmiah. Itu merupakan 
tantangan yang amat berat karena banyaknya jumlah guru yang membutuhkan jurnal sebagai media publikasi artikel ilmiah sementara jumlah jurnal sangat terbatas. Berdasarkan data LIPI jumlah jurnal ilmiah yang terakreditasi di Indonesia hanya sekitar 300 jurnal. Kepala Pusat Dokumentasi dan Informasi Ilmiah Lembaga Ilmu Pengetahuan Indonesia (PDII LIPI) Sri Hartinah mengatakan, jumlah jurnal ilmiah nasional terakreditasi yang dimiliki Indonesia masih sangat rendah. Dalam catatan LIPI, hingga saat ini, jumlah jurnal ilmiah (cetak) di Indonesia hanya sekitar 7.000 buah. Dari jumlah itu, hanya 4.000 jurnal yang masih terbit secara rutin dan hanya 300 jurnal ilmiah nasional yang telah mendapatkan akreditasi LIPI (Kompas.com, 7/2/2012).

Budaya tulis akan semakin tumbuh di kalangan guru dengan perkembangan teknologi informasi yang memfasilitasi guru untuk memudahkan menulis sebab hadirnya alat perekam dalam peralatan komunikasi memudahkan guru merekam aktivitas mengajarnya dan kemudian memindahkannya ke dalam video atau ke dalam teks.

Membaca dan menulis merupakan kewajiban bagi guru untuk mengembangkan wawasan dan mengembangkan potensi murid. Sudah selayaknya guru harus mulai berani untuk menulis dan meneliti dengan apa yang mereka kerjakan dalam profesinya. Dalam kenyataannya di lapangan masih banyak para guru dan tentu saja termasuk kepala sekolahnya (SD, SMP, dan SMA) yang masih perlu bantuan dalam meningkatkan keterampilan menulis. Hal itu juga terjadi di lingkungan SMA Negeri 1 Katapang. Untuk itu kami tim pengabdian kepada masyarakat dari Fakultas Ilmu Komunikasi Universitas Padjadjaran bertujuan untuk membantu mereka yang ingin meningkatkan keterampilan menulis, baik tulisan ilmiah maupun tulisan yang bersifat pendidikan untuk para guru

\section{TARGET DAN LUARAN}

Target luaran yang hendak dicapai adalah sebagai berikut.

1. Pelatihan peningkatan pendidikan dan pengembangan kompetensi guru guru SMAN I Katapang Kabupaten Bandung mengenai teknik membuat laporan tulisan ilmiah ini diharapkan akan dapat berguna bagi peserta khususnya untuk kepentingan kegiatan sejenis di masa yang akan datang serta para guru dapat membuat laporan atau tulisan ilmiah yang sifatnya standar.

2. Pengetahuan akan teknik membuat laporan tertulis yang sifatnya ilmiah bagi para guru dapat membantu mengembangkan potensi yang dimilikinya di masa yang akan datang.

3. Jabatan guru sekarang diakui sebagai jabatan fungsional, yang antara lain pengakuan prestasinya dilakukan melalui hasil tulisan (laporan ilmiah) baik untuk diterbitkan maupun tidak. Dengan demikian, kegiatan kursus menulis laporan ini sangat membantu dalam memecahkan sebagian masalah mereka dalam hal teknik menulis laporan.

4. Peserta pelatihan mempublikasikan karya tulisnya di media massa cetak.
5. Modul Penulisan Karya Ilmiah yang diajukan ke HAKI.

6. Sertifikat bagi peserta sebagai keterangan telah mengikuti pelatihan karya tulis ilmiah.

\section{BAHAN DAN METODE}

Dengan melihat berbagai kondisi seperti terungkap dalam permasalahan dan latar belakang di atas, pemecahan masalahnya dilakukan sebagai berikut.

1. Perlu diadakan semacam terobosan untuk mengatasi masalah kurangnya keterampilan menulis para guru, yakni melalui kegiatan kursus menulis secara sederhana, baik tulisan ilmiah maupun tulisan yang berkaitan dengan pendidikan.

2. Bentuk kursus menulis ini sifatnya praktis. Peserta diberi petunjuk teknis cara memulai menulis dengan benar, kemudian dilanjutkan dengan latihan menulis kepada peserta.

3. Dengan teknik praktis ini diharapkan peserta yang umumnya para orang dewasa menjadi lebih memahami akan teknik atau materi yang disampaikan.

Untuk mewujudkan kegiatan PKM ini Tim Dosen Fikom Unpad bersinergi dengan para guru SMA Negeri I Katapang dan pimpinan sekolah tentunya dijadikan mitra utama dalam penyelenggaraan kegiatan PKM ini. Dalam tataran pelaksanaannya PKM ini memiliki beberapa tahapan kegiatan yang dilakukan dalam rangka mempermudah pelaksanaan kegiatan tersebut. Adapun langkah-langkah kegiatan yang kami lakukan sebagai prosedur kerja yang mendukung realisasi kegiatan PKM ini adalah sebagai berikut.

\section{A. Persiapan}

1. Melakukan survei kebutuhan kepada masyarakat, khususnya potensi wilayah yang mencakup mengenai jenis kebutuhan yang perlu diselenggarakan dalam kegiatan PKM Tim Dosen Prodi Ilmu Humas Fikom Unpad ini.

2. Melakukan koordinasi dengan pihak sekolah dan unsur pimpinan masyarakat sekitar yang berada di wilayah Katapang Kabupaten Bandung.

3. Membuat perizinan pelaksanaan kegiatan PKM Tim Dosen Prodi Ilmu Humas dari pihak Fakultas atau Universitas Padjadjaran kepada SMA Negeri I Katapang Kabupaten Bandung yang rencananya akan dijadikan sebagai tempat dan lokasi pelaksanaan PKM Tim Dosen Prodi Ilmu Humas Fikom Unpad.

4. Menyerahkan dan mengkonfirmasi perizinan penyelengaraan kegiatan PKM Tim Dosen Prodi Ilmu Humas Fikom Unpad ke pihak sekolah untuk mendapatkan kepastian mengenai jadwal pelaksaanaan kegiatan penyebaran implementasi ilmu komunikasi bagi masyarakat (siswa dan guru di SMA Negeri I Katapang). 


\section{B. Pelaksanaan}

Semua permasalahan yang diusulkan dalam PKM ini dibahas secara lengkap. Dimulai dari pengertian tulisan ilmiah, semi ilmiah, laporan penelitian, modul, atau tulisan lain yang berkaitan dengan pendidikan, disampaikan secara praktis.

Pengertian judul, anak judul, latar belakang masalah, perumusan masalah, tujuan penulisan, manfaat tulisan, kerangka pemikiran, tinjauan kepustakaan, uraian dan analisis, metode penulisan, dan juga kesimpulan dan saran-saran, semuanya dibahas secara lengkap. Penyampaian materi dimaksud dilengkapi juga dengan diskusi mengenai masalah-masalah yang ditanyakan.

Di samping itu diadakan pula pelatihan singkat untuk membuat judul karangan dan tugas untuk membuat laporan karya ilmiah untuk kepentingan pendidikan. Para peserta juga diberi buku panduan menulis yang ringkas hasil fotokopi yang setiap saat bisa mereka manfaatkan.

Metode yang digunakan dalam kegiatan pengabdian kepada masyarakat ini adalah ceramah dan praktik/latihan menulis sederhana tentangberbagai masalah atau topik, baik tulisan berbentuk laporan ilmiah maupun tulisan untuk kepentingan pendidikan. melalui pelatihan ini nantinya diharapkan pengalaman tersebut bisa ditularkan kepada rekan sejawat dan para siswa

\section{Evaluasi}

Evaluasi di sini dilakukan dengan dua cara, yakni melalui tanya jawab langsung dengan pihak sasaran mengenai keberhasilan kegiatan ini di akhir pelaksanaan program; melalui hasil tulisannya selama mengikuti kegiatan kursus ini; dan melalui kegiatan pemantauan (monitoring) ke lapangan tentang kelanjutan dan efek kegiatan ini secara keseluruhan. Dari hasil evaluasi ini bisa ditentukan kegiatan lanjut, apakah perlu diteruskan pengembangannya atau sudah cukup.

Karena program kegiatan ini sifatnya berkelanjutan, pada waktu yang akan datang hasil dari kegiatan yang sekarang ini menjadi dasar untuk dilakukannya kegiatankegiatan selanjutnya. Untuk sementara yang didahulukan penggarapannya adalah pada upaya peningkatan keterampilan guru-guru pustakawan yang terlibat langsung dengan pengelolaan perpustakaan.

Keterlibatan mitra dalam pelaksanaan program pengabdian Tim Dosen Prodi Ilmu Humas Fikom Unpad pada tahun ini ditingkatkan dengan menyediakan fasilitas dan peserta yang representatif dalam mendukung kegiatan ini. Selain itu, mitra pengabdian mengharapkan bahwa SMA Negeri I Katapang ini dapat menjadi binaan secara berkelanjutan dan bervariasi dari sisi kegiatan PKM yang dilakukan Universitas Padjadjaran pada tahuntahun selanjutnya.

\section{HASIL DAN PEMBAHASAN}

\section{Hasil Kegiatan Pengabdian Kepada Masyarakat}

Program Peningkatan pendidikan dan pengembangan kompetensi guru melalui partisipasi dalam publikasi akademis di media massa di SMA
Negeri 1 Katapang menggunakan metode ceramah, tanya jawab, dan simulasi. Tujuan pelatihan ini adalah untuk meningkatkan pengetahuan dan keterampilan guru dalam membuat artikel ilmiah.

Kegiatan pelatihan dilaksanakan pada hari Sabtu, 09 November 2013 mulai 08.00 hingga 13.00 WIB, bertempat di SMA Negeri 1 Katapang dengan 16 peserta dari target 35 peserta.

Acara dimulai dengan sambutan dari perwakilan tim PKM Fakultas Ilmu Komunikasi Universitas Padjadjaran yang diwakili oleh Ketua Prodi Humas, Trie Damayanti, M.Si. yang diterima oleh Kepala Sekolah SMAN 1 Katapang. Penyambutan dilakukan secara simbolis yang dihadiri oleh perwakilan guru dan tim dosen.

Kegiatan pelatihan Program Peningkatan pendidikan dan pengembangan kompetensi guru melalui penulisan artikel ilmiah dimulai dari penjelasan mengenai dasar-dasar penulisan, sistematika penulisan, layout penulisan dan pemilihan topik topik yang akan di tulis.

Sesi pertama, peserta mendapatkan materi tentang dasar-dasar penulisan, peserta mendapatkan pengetahuan teoritik untuk penambahan kognisi, selama 1,5 jam dengan pembicara Dr. Hanny Hafiar, M.Si. Pada sesi pertama pelatihan yang diberikan bersifat penambahan pengetahuan untuk memberikan pemahaman para peserta secara logis dan ilmiah dalam menguraikan dan membahas suatu permasalahan serta dapat menuangkannya secara sistematis dan terstruktur.

Karya tulis ilmiah tersebut dapat berupa karya tulis ilmiah hasil penelitian, pengkajian, survei dan evaluasi, karya tulis/makalah berupa tinjauan atau ulasan ilmiah gagasan sendiri, tulisan ilmiah populer, prasaran berupa tinjauan wawasan atau ulasan ilmiah yang disampaikan pada pertemuan ilmiah, buku pelajaran atau modul, diktat pelajaran, penerjermahkan karya ilmiah, artikel, dan berbagai produk lain yang dapat dipublikasikan.

Karya tulis ilmiah yang ditulis guru hendaknya memenuhi syarat-syarat sebagai berikut:

1. asli (original), (bukan karya jiplakan) dan menjauhi duplikasi, maksudnya karya tulis yang dihasilkan harus merupakan produk asli guru dan sesuai denganbidang ilmu yang dimiliki serta permasalahan yang dihadapi di lingkungannya;

2. perlu/bermanfaat (useful), yakni karya tulis yang dihasilkan guru harus dirasakan manfaatnya secara langsung oleh guru dalam meningkatkan kualitas belajar-mengajar;

3. ilmiah (scientific), yakni karya tulis yang dihasilkan harus disusun secara ilmiah, sistimatis, runtut, dan memenuhi persyaratan penulisan karya ilmiah; dan

4. konsisten (concistency), maksudnya karya yang dihasilkan harus memperlihatkan keajegan dan konsistensi pemikiran yang utuh, baik secara keseluruhan maupun hubungan antarbab bagian karya tulis yang disajikan.

Perlu juga diperhatikan mengenai sifat dan isi tulisan dari sebuah karya tulis ilmiah sebagai berikut: 1. kreatif dan objektif, dimaksudkan agar tulisan tetap memperhatikan gagasan yang kreatif 
untuk menyelesaikan suatu permasalahan yang berkembang di masyarakat; dan

2. tulisan tidak bersifat emosional atau tidak menonjolkan permasalahan subjektif dan tulisan harus didukung oleh data dan/atau informasi terpercaya,

Selanjutnya setelah pemberian materi dilakukan diskusi tanya jawab mengenai materi yang telah disampaikan. Diskusi berlangsung cukup ramai dikarenakan peserta antusias terhadap materi pelatihan yang disampaikan.

Setelah rehat sesi kedua dilanjutkan dengan praktik menulis selama 2 jam, dengan dipandu oleh tim PKM Unpad. Mekanisme praktik menulis ini terdiri dari beberapa tahap:

a. peserta diminta menuliskan topik tulisan yang akan dibuat artikel ilmiahnya;

b. setelah topik tulisan disusun kemudian dibahas satu per satu oleh tim PKM mengenai fokus tidaknya topik dan judul yang akan dibuat;

c. setelah judul dan topiknya disusun peserta kemudian diberikan waktu 30 menit untuk menyusun sebuah draft tulisan karya ilmiah;

d. setelah selesai peserta maju ke depan kelas untuk mempresentasikan hasil karyanya dan dikomentari olehtim PKM dan peserta lainnya sebagai masukan; dan

e. yang terakhir, hasil presentasi disempurnakan kembali oleh peserta dan minggu depan, tim PKM kembali datang ke lokasi untuk melakukan monitoring.

\section{Pembahasan Kegiatan Pengabdian Kepada Masyarakat}

Kompetensi profesional seorang guru berhubungan dengan penyelesaian tugas-tugas keguruan dan berhubungan langsung dengan kinerja yang ditampilkan. Salah satu tuntutan profesional tersebut adalah kemampuan guru dalam melaksanakan penelitian dan berpikir ilmiah untuk meningkatkan kinerja. Kenyataannya, tuntutan kompetensi tersebut bukan suatu tugas atau sesuatu hal yang mudah bagi para guru. Pada umumnya para guru belum faham akan penyusunan karya tulis ilmiah.

Perkembangan ilmu pengetahuan dan teknologi yang semakin maju, seharusnya dapat memicu semangat para guru untuk beraktivitas dalam menyemarakkan dunia pengetahuan. Pada dasarnya guru mempunyai segudang ide untuk diungkapkan. Salah satunya bersumber dari permasalahan yang ada di sekitarnya, khususnya dalam proses belajarmengajar di dalam kelas, tetapi guru kurang memahami dan akhirnya belum dapat menuangkannya ke dalam sebuah karya tulis ilmiah yang layak untuk dipublikasikan dan dikonsumsi masyarakat.

Setelah kegiatan PKM (Pengabdian Kepada Masyarakat) ini selesai dilaksanakan ada beberapa hal yang telah dapat dihasilkan baik bagi Tim maupun peserta yang menjadi target sasaran dari kegiatan ini. Beberapa hal tersebut di antaranya sebagai berikut.

1. Terlaksananya upaya untuk melakukan kegiatan pengabdian pada masyarakat yang menjadi tugas pokok dan fungsi kami (tim) sebagai sivitas akademika perguruan tinggi (Unpad).

2. Terciptanya hubungan yang baik antara kami yang mewakili institusi Unpad dengan masyarakat, khususnya dengan para pendidik, pengelola sekolah dan siswa-siswa SMAN 1 Katapang.

3. Terjalinnya kerjasama yang erat ditindaklanjuti dengan adanya harapan untuk dapat terus membina kerjasama ini dimasa yang akan datang.

4. Tersampaikannya materi penulisan artikel yang dapat memberikan bekal pengetahuan dan keterampilan kepada guru di SMAN 1 Katapang. Setiap materi disampaikan oleh semua anggorta Tim bertujuan untuk meningkatkan pengetahuan dan keterampilan para peserta PKM.

5. Peserta cukup antusias untuk mengikuti setiap materi yang disampaikan berikut praktik yang dilakukan secara bersama-sama sehingga tidak hanya pengalaman secara kognisi dan afeksi saja yang mereka peroleh selama mengikuti pelatihan ini. Namun, mereka juga mendapatkan pengalaman secara praktis (psikomotorik) sehingga mereka jauh lebih mudah untuk memahami setiap materi yang disampaikan.

6. Kegiatan ini menimbulkan tanggapan yang cukup positif. Mereka sangat mengharapkan apa yang sudah mereka dapatkan selama mengikuti pelatihan ini dan akan mencoba untuk menulis beberapa artikel dan akan mencoba mengirimnya ke media cetak.

7. Bahan materi pelatihan dan modul yang diberikan secara cuma-cuma sangat bermanfaat bagi setiap peserta karena mereka berpendapat bahwa selama ini kesulitan untuk mendapat panduan yang bersifat praktis untuk menulis sebuah artikel.

Seorang guru dapat mengembangkan kemampuannya menulis karya ilmiah dan manfaat yang dapat diperoleh antara lain:

a. melatih mengembangkan keterampilan membaca;

b. melatih menulis dari berbagai sumber dan mengembangkannya ke tingkat pemikiran yang lebih matang;

c. memperluas cakrawala ilmu pengetahuan;

d. memperoleh kepuasan intelektual; dan

e. menambah angka kredit bagi guru.

Secara umum kegiatan ini dinilai cukup berhasil dari segi perencanaan, pelaksanaan maupun hasil kegiatan pelatihan secara umum. Hal itu tergambar dari komentar, tanggapan maupun permintaan para peserta yang menginginkan kegiatan serupa di masa mendatang baik dengan materi yang sama maupun berbeda.

\section{SIMPULAN}

Kegiatan Pengabdian kepada Masyarakat bertema Peningkatan Pendidikan dan Pengembangan Kompetensi Guru melalui Partisipasi dalam Publikasi Akademis di Media Massa di SMA Negeri 1 Katapang dapat membantu mengatasi keterbatasan peserta (guru) dalam hal: 
1. pengetahuan dan keterampilan mengenai penulisan artikel;

2. sistematika penulisan artikel; dan

3. jenis-jenis artikel.

Kegiatan pelatihan ini sebagai sebuah upaya bimbingan teknis, khususnya dalam meningkatkan dan mengembangkan potensi guru dalam hal menulis. Dengan demikian diharapkan budaya membaca dan menulis dapat dioptimalkan.

\section{DAFTAR PUSTAKA}

Rooijakkers, Ad. 1991. Mengajar dengan Sukses: Petunjuk Umum untuk Merencanakan dan Menyampaikan Pengajaran. Jakarta: Grasindo.

Shores, Louis. 1968. Instructional Materials: An Introduction for Teachers. New York: Ronald Press.

Susanto, Astrid S. 1985. Pengantar Sosiologi dan Perubahan Sosial. Bandung, Binacipta.

Utomo, Tjipto dan Kees Ruijter. 1991. Peningkatan dan Pengembangan Pendidikan. Jakarta: Gramedia Pustaka Utama. 